\title{
RESEARCH ARTICLE MARKETING MANAGEMENT PERFORMANCE ANALYSIS FOR CHIT FUND COMPANIES IN SELECTED DISTRICTS OF TAMILNADU
}

\author{
P. Shunmugathangam* \\ Faculty of Business Administration, Sri Sarada College for Women, Tirunelveli District, Tamilnadu, India \\ *Corresponding Author Email: dr.m.thangam2017@gmail.com
}

This is an open access article distributed under the Creative Commons Attribution License, which permits unrestricted use, distribution, and reproduction in any medium, provided the original work is properly cited.

\section{ARTICLE DETAILS}

\section{Article History:}

Received 10 August 2019 Accepted 18 September 2019 Available online 25 September 2019

\section{ABSTRACT}

Chit funds have been a popular savings scheme in several parts of India for generations together now. It has paved its way as a convenient finance option amongst businessmen, small scale industrialists, and other small-time investors. Though very often shrouded by news of fraudulence, they have still managed to retain their popularity. So, what exactly are chit funds and how efficient a financial tool is it? Read on to find out more. Chit funds evolved years ago, when the present system of banking did not exist. Few families in a village would get together to form a chit or a group, to save money and to avail of loans amongst the group formed. A sensible person is chosen to manage the group. This informal system of saving prevailed only on trust. This study is to evaluate the "A Marketing Management Performance Analysis of Registered Chit Funds Companies in Tamilnadu." The research concentrates on the financial performance of registered and unregistered chit fund marketing performance of chit fund companies. The area of the study is Trichy, Tripur and Erode in registered, unregistered chit fund companies and general public also covered this area. The research is to identify what are the marketing management performances to make in the registered and unregistered chit fund companies and to compare the performance of registered and unregistered chit fund companies' subscribers.

\section{KEYWORDS}

Chit funds, Investors, Fraudulence, Marketing performance, Finance performance.

\section{INTRODUCTION}

Chit funds have been a popular savings scheme in several parts of India for generations together now. It has paved its way as a convenient finance option amongst businessmen, small scale industrialists, and other smalltime investors. Though very often shrouded by news of fraudulence, they have still managed to retain their popularity. So, what exactly are chit funds and how efficient a financial tool is it? Read on to find out more.

Chit funds evolved years ago, when the present system of banking did not exist. Few families in a village would get together to form a chit or a group, to save money and to avail of loans amongst the group formed. A sensible person is chosen to manage the group. This informal system of saving prevailed only on trust. Gradually, as groups became larger and the money involved became huge, many companies started chit fund schemes with attractive offers. To thus provide for the regulation of chit funds and for matters connected therewith, the government introduced the chit funds act in 1982.

A chit fund is a savings borrowing scheme, in which a group of people enter into an agreement to contribute fixed amounts periodically, for a specified period of time. The amount so collected (or the chit value) is distributed among each of the persons in turns, which is determined by way of lots or an auction. Chit funds provide an opportunity to save excess cash on a daily, weekly or monthly basis, and give an easy access to it in case of emergency.

Chit fund schemes possess a predetermined chit value and duration. The amount collected from members is auctioned out every month. Bidders can bid up to a maximum of this total collected value. The difference between the gross sum collected and the actual auction amount, known as the discount, is then equally distributed among subscribers, or, is deducted from the next month's premium.

\subsection{Statement of the Problem}

The reason why some of the chit funds companies in Tamilnadu in recent years defaulted to the customers are collecting deposits from the public by corresponding thousands of customers, assuring them high interest rates than banks and investing crore of rupees collected from the thousands of people and interested these amount in real estate business, finance business and movie making business and up with huge loses and failed to pay the amounts due to customers. These companies are collecting deposits on personal guarantee without leaving the opportunity to the count to seat their other business.

Operational costs like salaries, office rent, stamp duties, paper works and office equipment costs etc., are very high in registered chit fund companies but unregistered chit fund companies the costs is low. The $5 \%$ commission is insufficient to meet the operational costs. Though the registered chit fund companies enjoys the first bid amount without the first bid amount without any deduction the liquidity problem arises because of $100 \%$ chit amounts deposits with the unregistered chit fund companies.

Diversion of funds into other business, into other business delaying the payment to the subscribers, attracting deposits from the public conducting unregistered chits in the roof of registered chit fund companies are some of the real practice practiced by the chit fund companies.

Lack of control and regulation on unregistered business: The unregistered companies creating unhealthy condition to the industry most of the registered companies are training to be unregistered firms as these are no stringent norms and conditions and contract over the business.

Lack of financial planning and discipline the registered fund companies and subscribers. The unregistered chit fund companies' financial performance is wealth into the registered chit fund companies. Most of the registered chit fund companies default because of the irregular and 
delayed payment of future subscription by the subscribers well established and financially sound companies appointing agents for selecting good customers.

Registered chit fund companies are away from low income group. For registered chit fund companies it is not profitable to run low value chit funds as the commission charges is low. Low income people preferring unregistered companies as there are no rules and stringent norms and collateral requirements will the companies.

The registered chit fund companies subscriber's performance is poor into the unregistered chit fund companies. Present study to identify the problems of registered chit fund companies.

\section{SCOPE OF THE STUDY}

The scope of this study is to evaluate the "A Marketing Management Performance Analysis of Registered Chit Funds Companies in Tamilnadu". The research concentrates on the marketing performance of registered chit fund companies. The area of the study is Trichy, Tripur and Erode in registered, unregistered chit fund companies and general public also covered this area. The research is to identify what are the performances to make in the registered and unregistered chit fund companies.

\section{OBJECTIVES AND HYPOTHESIS OF THE STUDY}

\subsection{Objectives of the Study}

The overall objective is to evaluate the "A Marketing Management Performance Analysis of Registered Chit Funds Companies in Tamilnadu". To achieve overall objective have been established, these are:

1. To study the organisation structure of Tamilnadu government registration department.

2. To analyse the marketing performance of registered and unregistered chit funds institutions at selected districts in Tamilnadu.

\subsection{Hypothesis of the Study}

1. There is no significant difference between performance of subscribers on the marketing dimension of product (schemes) between registered and unregistered chit fund companies in Tamilnadu.

2. There is no significant difference between performance of subscribers on the marketing dimensions of price (chit value) between registered and unregistered chit funds companies in Tamilnadu.

\section{REVIEW OF LITERATURE}

This study is an attempt to review progress of sugar industry in India both in financial and micro economic terms and understand its problems and challenges in context of an going liberzation process based on sound financial fundamentals Indian sugar industry can be global leader provided it comes out of shortage and surplus of sugarcane, lower sugarcane yield, lower sugar recovery, ever increasing production costs and mounting losses. This study aims to throw light on the present situation of the Indian sugar industry, discussing the indicate details of the industry from financial and micro economic profit of view etc., this study aims to provide and insight into the financial viability and profitability of Indian sugar industry. Secondary data has been used to this study [1]

This study shows to compare the financial performance of the selected units i.e. sail and Tata steel ltd. While analyzing the financial performance of the selected units, include the analysis of working capital and analysis of profitability. It concluded that the performance of Tata steel ltd. is better than the sail It is so because the net profit of Tata steel ltd. is greater than the sail. Similarly, the inventory management of the Tata steel ltd. is better than the sail [2].

The purpose of this study is to contrast the financial performance on oil and gas sector before and after global crisis. On this research the financial performance will examine with three ratio perspectives, profitability ratio, liquidity ratio, and market ratio. Three companies are selected by purposive sampling technique. The data type is secondary data which collected by financial report per quarter. The period was divided to two periods, before global financial (2006- 2008) and after global crisis (20092011). The result found that return on asset, return on equity, current ratio, and quick ratio indicate significant difference performance during period of before global crisis and after global crisis. In the other hand price-earnings ratio is not indicated significant ratio through the before and after global crisis period [3].

The purpose of this research, ranking the bank listed in Tehran Stock Exchange, according to financial criteria. After a comprehensive review of the research literature and the idea of financial experts have been identified criteria to assess the financial performance of banks in the aspects of liquidity factors, factors, profitability, and capital adequacy and risk asset structure factors. To increase the accurateness of the study, the weight of financial factors calculates with AHP-FUZZY method. Finally, the final weights obtained, the ELECTRE algorithm has been applied to rank the banks. The results show that the KAR AFARIN bank is on top and ANSAR Bank, PASARGAD and the EGHTESAD NOVIN were ranked second, third and fourth and the MELAT bank, SADERAT and TEJARAT got the ratings from the eighth to the tenth [4].

This paper examines the financial performance analysis of Ashok Leyland company ltd. The study was based on secondary data. Data relating of liquidity, solvency and profitability position from the balance sheet and profit \& loss account of Ashok Leyland. The necessary data were obtained from published annual report. It is found that the company was able to meet its entire requirements for capital expenditures and higher level of working capital commitment with higher volume of operations and from its operating cash flows [5].

The study analyzing the financial statement of balance sheet covers the period of 2008-2012. This study finds out the financial position (i.e.) operating, non-operating incomes and how to control the cost of the enterprise and allocation of resources to improve the financial performance. The study is based on the secondary data collected from annual reports. It found that that there was a continuous increase in net income when compared with the expenditure of the organization. Just in time for managing the inventories it is not much effective to reach their organization goals and objectives [6].

This research paper is aimed to analyse and compare the financial performance of ICICI bank and offer suggestions for the improvement of efficiency in the bank. The period of the study was 2009-2010 to 20132014. Secondary data was collected from annual reports of the company. The financial performance of the ICICI bank has been analyzed by grouping the financial ratios through liquidity ratios, profitability ratio and activity ratio as it is an important technique of financial statement analysis [7].

This study analyses that PNB has the highest return on Net Worth (mean) which is a sign that management of Punjab national bank is at using leverage to increase profits and profit margins. The study is done with special reference to top five Indian banks. Top five Indian Banks are chosen as sample size for the study on the basis of market capitalization. The study has been conducted during March 2009 to March 2014. SBI and PNB has the highest return on capital employed (mean) which indicates that SBI and PNB are realizing highest return from its capital employed. State bank of India has highest Dividend Payout Ratio (Mean) which is a sign that the SBI has highest percentage of profit distribute as dividend to equity shareholders. Bank of Baroda has the return on assets (mean) which is a sign that management of bank is using assets fund more efficiently to increase earning capacity. It is also suggested that bank of India has lowest divided per share and earnings per share so bank has improved its profit accordingly increase in its DPS EPS [8].

This study examines the financial performance of an investment company in India for a three years period from 2010 to 2013, which is assessed using cash flow statement. This study utilized the quantitative research methodology. The findings pointed out that overall company performance reduced remarkably in the last year of the analysis. This study principally highlights on how accounting information aids budgetary decision-makers to evaluate the company financial performance, determine its future obligations, and make better investment decisions [9].

This study compacts with financial performance of private banks in Pakistan. The data is collected from financial statements analysis of financial sector issued by state bank of Pakistan. Data has been collected from financial statement analysis of financial sector 2006-2010. The sample size consists of top ten private commercials banks of Pakistan. It is used regression analysis and correlation technique in order to address the 
issue. Bank size and operational efficiency is negatively related with ROA and positive relationship was found with assets management ratio. While, bank size is positively related with interest income and asset management and operational efficiency is negatively related with interest income [10].

This research shows cement industry in India to find out the overall financial performance efficiency. Twelve years data has been employed in this study from 2001-2002 to 2012-2013. Ratio analysis and compound aggregate growth rate (CAGR) was used to find out the overall performance efficiency. It found that the cement industry performance was good in India during the study period. It concludes that the cement companies in India have to consolidate in order to become strong, vibrant and also they have to concentrate on export market [11].

The purpose of this study is to compare the financial performance of state and private sector banks during war and post war scenarios of Sri Lanka. This study is initiated as a comparative study of financial performance of commercial banks in Sri Lanka from the financial year 2007-2012. This study was done in Sri Lanka. Researchers selected two state and two private commercial banks for this study ratio and descriptive analysis are widely used for measuring and comparing the financial performance and position of banks. Accordingly descriptive analysis confirmed that, private banks had high financial performance than state banks during war, post war state banks should focus to increase their financial performance to compete and survive successfully in the current world and also private commercial banks try to achieve their target financial performance for their long survival [12].

This research aims to study on financial performance of Honda and Toyota automobile company a comparative analysis. The period for this study covered five years from 2009-2010 to 2013-2014 and the essential data for this study have been collected from the annual reports of two companies (Honda \& Toyota). It appears safe to summarize that the Honda \& Toyota seems to be sound financial management practice. The study is based on convenience sampling method. In conclusion it appears safe to summarize that the Honda \& Toyota seems to be sound financial management practice [13].

The objective of this study is to analyze the financial position and performance of the bank of Baroda and Punjab national bank in India based on their financial characteristics. This study attempts to measure the relative performance of Indian banks. This study used the CAMEL model and t-test which measures the performance of bank from each of the important parameter like capital adequacy, asset quality, and management efficiency, earning quality, liquidity and sensitivity. The study is based on secondary data. The study covers a period of five year from 2010-2014. It concluded that transparency and good governance would work as principal guiding force in present scenario [14].

This project report on ratio analysis assesses the financial strengths and weakness of carborundam universal ltd., Hosur through financial ratio analysis. To evaluate the performance of the company by using ratios as a yardstick to measure the efficiency. To understand the liquidity, profitability and efficiency positions of the company during the study period. This study has made an attempt to make comparisons between the ratios during different periods. Convenience sampling method was used. Finally, it concludes that financial position of carborundam universal limited, Hosur is in progressive satisfactory. The company has every opportunity to get its growth to a good and extent in future [15].

The project work is "A study on financial performance analysis of spinning mills of Coimbatore city". The study was carried out for the period of five years (2010-2014) to analyze the financial performance of the company and the five companies are Lakshmi Mills, Bannari Amman Spinning Mill, Sri Ramakrishna Spinning Mill, KPR Spinning Mill and Super Spinning Mill are taken for study. The research design of the study is descriptive research design and secondary data was collected from the published websites of organization for the research. The tools used for analysis is comparative ratio analysis of the balance sheet. The findings from the analysis were discussed in detail and suggestions for corrective actions like maintain good solvency in order to meet short term and long-term obligations were given wherever applicable [16].

The basic purpose of the study is to understand and analyze the financial performance of the selected companies. The two selected groups of companies (i.e., NBFC's and banking companies) provide a variety of services at differential rates between the two groups within the particular period of 5 years (2007-2011). The study is descriptive and diagnostic in nature. This study is extensively based on the secondary data sources. From the study it was found that NBFC's are showing better position in the capital markets than the selected banking companies. This means, the NBFC's have good reputation in the capital market because of its principle activities. The companies differ significantly in terms of their financial performance indicators from one company to another. Earnings per share of the selected companies increased over the last five years, whereas the operating profit per share of all companies showed an increasing trend from the year 2007 to 2010 and depicted a slight dim in the year 2011. Overall, the NBFC's have performed well, as and when compared to the banking companies [17].

The present researcher to identify the research gap for these types of review of literature only studied in the financial performance of registered chit fund companies. The present study to study about "a marketing management performance analysis of registered chit funds companies in Tamilnadu".

\section{RESEARCH METHODOLOGY}

A systematic process and methodology is needed to conduct a research in a successful manner. This section highlights the methodology and process used to conduct the present research. This section highlights the objectives and procedure of the study. Further, this section discusses the research methodology adopted for attaining the objectives of the study. Properly conducted research reduces the uncertainty level for the top management in making critical decisions. Hence it is extremely important to describe the research methodology here.

\section{$5.1 \quad$ Research Type}

Type of research based on the nature of data. In the light of the nature of data, the present research is mainly of a quantified nature, as most research mainly of a quantified nature, as most of the findings of the present study are based on quantified measure. However, the researcher also manipulated the casually and consequences, which also represented a sign of qualitative research. In the light of purpose of research, the present study was mainly applied nature as the researcher tried to test the comparative performance analysis of registered chit fund companies in Tamilnadu. Further, the survey method was adopted by selecting and studying a sample chosen from the population (registered and unregistered chit fund companies to their subscribers, to discover the relevant incidence, distribution and interrelation of variables.

\subsection{Research Design}

Reliability and validity of the research required planning of inquiry, i.e. the detailed strategy of how the research would be conducted. A good research design depends on two aspects of its designing: first, specifying what one wants to find out, i.e., properly posing the problem or properly phrasing the issues to be studied or the logical structure of inquiry; and second, determining how to do it, i.e., collecting data through scientific and appropriate methods, using effective techniques of data analysis and rational and meaningful deductions. Therefore, the researcher had to take great care in the preparation of the research design. There are many types of research design and there was no standard or ideal research design to guide the researcher; much different research design may accomplish the same objectives. Broadly, research design can be of three types: 1) exploratory, 2) descriptive and 3) casual / experimental.

In the present study, mainly exploratory research design had been adopted, as the main purpose of this study was to make comparative study of registered and unregistered chit fund companies and also general public opinion towards chit fund business. Since the scope of the study was very vast, the present study also represented some characteristics of descriptive research design.

\subsection{Sampling Design / Plan}

An explicit plan for obtaining samples from given population is known as sampling design. It is an overall plan for selecting objects from the universe before survey is undertaken. Sample designing process requires following items to be define clearly because they are closely interrelated and relevant to all aspects of research, from problem definition to the presentation of the result. 


\subsubsection{Universe (Population of Interest)}

Population refers to any group of people or objects that form the subject of study in a particular survey and are similar in one or more ways. Target population is defined as a specific group of people or objects for which the data can be gathered or observation made to develop required data structure and information. In present study, those registered and unregistered chit fund subscribers from Trichy, Tripur and Erode in Tamilnadu the comparative performance were analyse from the study.

\subsubsection{Sampling Element}

An element comprises a single member of the population. For present study, subscribers considered as sampling element.

\subsubsection{Sample Size Determination}

The size of sample depends upon the basic characteristics of the population, the type of information required from the survey and the cost involved. The most commonly used approach for determining the size of sample is the confidence interval approach covered under inferential statistics. The confidence interval approach to sample size determination is based on the construction of confidence intervals around the sample means or proportions using the standard error formula. As the population mean is not known and as the statistic of interest is a proportion rather than mean, the proportions method of estimating sample size is used in this study. Following criteria have been considered for calculating sample size.

a) Sample size determination in registered chit fund companies-known population

$\mathrm{n}=\mathrm{Z}^{2}$ pqN / (N-1) $\mathrm{e}^{2}+\mathrm{Z}^{2}$ pq ( $\mathrm{Z}=\mathrm{Z}$ value e.g. 1.96 for $95 \%$ confidence level, $\mathrm{p}=$ population proportion (expressed as decimal) (assumed to be 0.5 $(50 \%)$ since this would provide the maximum sample size, $\mathrm{n}=$ sample size for finite population.

Total numbers of subscribers registered chit fund companies in Trichy, Tirubur, Erode districts - 36320 .

Sample size determined in subscribers - 381

b) Sample size determination in unregistered chit fund companiesknown population

$\mathrm{Ss}=\mathrm{Z}^{2} *(\mathrm{P})^{*}(1-\mathrm{P}) / \mathrm{e}^{2}$

Ss = sample size

$\mathrm{Z}=\mathrm{Z}-$ value $^{\mathrm{A}}$ (e.g. 1.96 for a $95 \%$ confidence level) $\mathrm{P}=$ percentage of population

$\mathrm{C}=$ confidence interval

\subsubsection{Sampling Method / Sampling Technique}

Sampling is a process of selecting an adequate number of elements from the population so that the study of the samples will not only help in understanding the characteristics of the population but will also enables to generalize the results. Broadly, sampling methods can be classified in two groups; 1) Probability and 2) Non-probability sampling. In registered chit fund companies the sampling method were used for probability proportionate stratified random sampling method. Those registered and unregistered chit fund companies subscriber have comparative performance identified in chit fund companies were selected districts in Tamilnadu and requested to participate in the survey.

\subsubsection{Sampling Frame}

Sampling frame encompass all the elements of a population with proper identification that is available to researcher for selection at any stage of sampling. Where the population size is very large, it becomes virtually impossible to form a sampling frame. In present study also, as population of unregistered and general public is very large and not possible to identify clearly, it is very difficult to form sampling frame for the same and as population of registered chit fund companies' foreman, employees, subscribers is very large and possible to identify clearly, it is very difficult to form sampling from for the same. In following table sampling frame in registered chit fund companies' foreman, employees, subscribers in selected districts from Trichy, Tripur and Erode in Tamilnadu.

\subsubsection{Method of Data Collection}

For this research primary as well as secondary data have been used for further analysis. Secondary data used to develop theoretical framework and to get insight into the research problem. Secondary data have been collected from published authenticated material such as magazines, journals, newspapers, internet, books and company annual reports. In present study, secondary data for the period from 2013 to 2015 have been used.

Primary data is original, problem or project specific and collected for the specific objectives and needs spelt out by the researcher. Primary data might be qualitative or quantitative in nature. Primary qualitative data collection is in-depth and collected through a more interactive and unstructured approach. Qualitative data collection method includes observation, focus groups study, in-depth interviews, content analysis etc. For this study, researcher has conducted focused interview with registered and unregistered chit fund companies' subscriber to get insight into the problem.

To collect quantitative primary data, structured schedule was developed schedule has been prepared into four types of schedule. While filling - up the schedule, it was personally administered and explained to respondents to ensure accurate collection of data.

\subsubsection{Data Analysis and Software Used for Data Analysis}

For analyzing data, descriptive statistics, Chi-square test, factor analysis and ANOVA, T-test were, trend analysis used with the help of Microsoft excel and SPSS (Statistical Software for Social Study) software.

\section{MAJOR FINDINGS}

6.1 Objectives - To Analyse the Marketing Performance of Registered and Unregistered Chit Fund Companies

6.1.1 Gender classification of the registered and unregistered chit funds companies subscribers

Table 1: Gender classification of the registered and unregistered chit funds

\begin{tabular}{|c|c|c|c|c|c|}
\hline \multirow{2}{*}{ S. No. } & Gender & \multicolumn{2}{|c|}{$\begin{array}{c}\text { Registered Chit Fund } \\
\text { Companies-Subscribers }\end{array}$} & \multicolumn{2}{c|}{$\begin{array}{c}\text { Unregistered Chit Fund } \\
\text { Companies-Subscribers }\end{array}$} \\
\hline & & Number & Percentage & Number & Percentage \\
\hline \multirow{2}{*}{1} & Male Female & $\mathbf{1 7 4}$ & $\mathbf{4 5 . 7}$ & $\mathbf{2 3 4}$ & $\mathbf{6 0 . 9}$ \\
2 & & $\mathbf{2 9 7}$ & $\mathbf{5 4 . 3}$ & $\mathbf{1 5 0}$ & $\mathbf{3 9 . 1}$ \\
\cline { 2 - 6 } & Total & $\mathbf{3 8 1}$ & $\mathbf{1 0 0 . 0}$ & $\mathbf{3 8 4}$ & $\mathbf{1 0 0 . 0}$ \\
\hline
\end{tabular}

Source: Primary Data

Interpretation:

The registered chit fund companies $54.3 \%$ of the respondents invested for this chit funds for female respondents and $45.7 \%$ of the male respondents invested their funds and $60.9 \%$ of the respondents male respondents invested their un registered chit funds and female respondents 39.1 of the respondents invested for their chit funds.

\subsubsection{Reason for selecting}

Table 2: Reason for selecting

\begin{tabular}{|c|c|c|c|c|c|}
\hline \multirow{2}{*}{ S. No. } & \multirow{2}{*}{$\begin{array}{l}\text { Reason for } \\
\text { Selecting }\end{array}$} & \multicolumn{2}{|c|}{$\begin{array}{l}\text { Registered Chit Fund } \\
\text { Companies-Subscribers }\end{array}$} & \multicolumn{2}{l|}{$\begin{array}{l}\text { Un-registered Chit Fund } \\
\text { Companies-Subscribers }\end{array}$} \\
\cline { 3 - 6 } & & Number & Percentage & Number & Percentage \\
\hline & Goodwill & $\mathbf{2 2}$ & $\mathbf{5 . 8}$ & $\mathbf{1 1}$ & $\mathbf{2 . 9}$ \\
\hline 2 & Experience & $\mathbf{1 0 0}$ & $\mathbf{2 6 . 2}$ & $\mathbf{1 0 6}$ & $\mathbf{2 7 . 9}$ \\
\hline 3 & Trust & $\mathbf{1 7 1}$ & $\mathbf{4 4 . 9}$ & $\mathbf{1 7 9}$ & $\mathbf{4 6 . 6}$ \\
\hline 4 & Heritage & $\mathbf{8 8}$ & $\mathbf{2 3 . 1}$ & $\mathbf{8 8}$ & $\mathbf{2 2 . 9}$ \\
\hline & Total & $\mathbf{3 8 1}$ & $\mathbf{1 0 0 . 0}$ & $\mathbf{3 8 4}$ & $\mathbf{1 0 0 . 0}$ \\
\hline
\end{tabular}

Source: Primary Data Interpretation: 
The registered chit find company's subscribers reason for selecting the chit funds the $44.9 \%$ of the respondents trust based the selecting the funds and $26.2 \%$ of the respondents experience based invested the chit funds and The un register chit find company's subscribers reason for selecting the chit funds the $44.9 \%$ of the respondents trust based the selecting the funds and $26.2 \%$ of the respondents experience based invested the chit funds. The majority of the respondent's trust based selected the registered and unregistered chit funds.

\subsubsection{From source did you come to know about in this company?}

Table 3: Sources to know

\begin{tabular}{|c|c|c|c|c|c|}
\hline \multirow{2}{*}{ S. No. } & \multirow{2}{*}{$\begin{array}{c}\text { Long Have Been } \\
\text { Working }\end{array}$} & \multicolumn{2}{|c|}{$\begin{array}{c}\text { Registered Chit Fund } \\
\text { Companies-Subscribers }\end{array}$} & \multicolumn{2}{|c|}{$\begin{array}{c}\text { Un-registered Chit Fund } \\
\text { Companies-Subscribers }\end{array}$} \\
\cline { 3 - 6 } & Number & Percentage & Number & Percentage \\
\hline 1 & $\begin{array}{c}\text { Electronic } \\
\text { media }\end{array}$ & $\mathbf{4 2}$ & $\mathbf{1 1 . 0}$ & $\mathbf{1 3}$ & $\mathbf{3 . 4}$ \\
\hline 2 & Print media & $\mathbf{1 4 4}$ & $\mathbf{3 7 . 8}$ & $\mathbf{8 2}$ & $\mathbf{2 1 . 4}$ \\
\hline 3 & Company agent & $\mathbf{1 4 9}$ & $\mathbf{3 9 . 1}$ & $\mathbf{1 8 6}$ & $\mathbf{4 8 . 4}$ \\
\hline 4 & $\begin{array}{c}\text { Relatives and } \\
\text { friend }\end{array}$ & $\mathbf{4 6}$ & $\mathbf{1 2 . 0}$ & $\mathbf{1 0 3}$ & $\mathbf{2 6 . 2}$ \\
\hline & Total & $\mathbf{3 8 1}$ & $\mathbf{1 0 0 . 0}$ & $\mathbf{3 8 4}$ & $\mathbf{1 0 0 . 0}$ \\
\hline
\end{tabular}

Source: Primary Data Interpretation:

The registered chit funds companies subscribers did you come to know about this company for $39.1 \%$ of the respondents to invested for chit funds for company agent and $37.8 \%$ of the respondents invested the registered chit funds for print media and The un registered chit funds companies subscribers did you come to know about this company for $48.4 \%$ of the respondents to invested for un registered chit funds for company agent and $26.4 \%$ of the respondents invested the un registered chit funds for relatives and friends. The majority of the respondents $39.1 \%$ of the respondents to invested for chit funds for company agent and the unregistered chit funds companies subscribers did you come to know about this company for $48.4 \%$ of the respondents to invested for un registered chit funds for company agent.

\subsubsection{Testing of Hypothesis Chi-square test}

Chi-square test hypothesis framed by:

Hypothesis H01: Age of the foreman will not have any influence on type of chits.

Hypothesis H02: Gender and the type of chit funds are independent. Hypothesis H03: Education has no effect on the type of chit funds. Hypothesis H04: Income range and preference of chit funds are independent.

Table 4: Demographical factors verses type of chit funds

\begin{tabular}{|c|c|c|c|c|c|}
\hline & \multicolumn{4}{|c|}{ Type of Chit Fund } & \multirow[b]{2}{*}{ Test Values } \\
\hline $\begin{array}{l}\text { Demographical } \\
\text { Factors }\end{array}$ & Registered & Unregistered & Mean & $\begin{array}{l}\text { Standard } \\
\text { Deviation }\end{array}$ & \\
\hline $\begin{array}{c}\text { Gender Male } \\
\text { Female }\end{array}$ & $\begin{array}{c}116(84.74) \\
21(15.3)\end{array}$ & $\begin{array}{c}119(62.0) \\
73(38.0)\end{array}$ & $\begin{array}{l}3.51 \\
4.05\end{array}$ & $\begin{array}{l}1.402 \\
0.809\end{array}$ & $\begin{array}{c}\text { Chi-square } \\
\text { value } \\
-44.850\end{array}$ \\
\hline $\begin{array}{c}\text { AgeBelow } \\
30 y r s 31- \\
40 y r s \\
41-50 y r s \\
\text { Above } 51 \text { yrs } \\
\end{array}$ & $\begin{array}{l}15(10.9) \\
36(26.3) \\
62(45.3) \\
24(17.5)\end{array}$ & $\begin{array}{l}36(18.8) \\
87(45.3) \\
40(20.8) \\
29(15.1)\end{array}$ & $\begin{array}{l}3.29 \\
3.05 \\
3.86 \\
4.25\end{array}$ & $\begin{array}{l}0.793 \\
0.453 \\
0.589 \\
0.308\end{array}$ & $\begin{array}{c}\text { Chi-square } \\
\text { value } \\
-4.950\end{array}$ \\
\hline $\begin{array}{c}\text { Education Up } \\
\text { to HSC } \\
\text { UG PG } \\
\text { Professional } \\
\text { Others } \\
\end{array}$ & $\begin{array}{l}34(24.8) \\
48(35.0) \\
29(21.2) \\
14(10.2) \\
12(8.8) \\
\end{array}$ & $\begin{array}{c}103(53.6) \\
32(16.7) \\
27(14.0) \\
12(6.3) \\
18(9.4) \\
\end{array}$ & $\begin{array}{l}3.01 \\
3.53 \\
3.48 \\
4.08 \\
4.96 \\
\end{array}$ & $\begin{array}{l}0.498 \\
0.476 \\
0.501 \\
0.458 \\
0.499 \\
\end{array}$ & $\begin{array}{c}\text { Chi-square } \\
\text { value } \\
-1.086\end{array}$ \\
\hline $\begin{array}{c}\text { Income Below } \\
10000 \\
10001-15000 \\
15001-20000 \\
20001-30000 \\
\text { Above } 30001\end{array}$ & $\begin{array}{c}38(27.7) \\
25(18.3) \\
49(35.8) \\
18(13.1) \\
7(5.1)\end{array}$ & $\begin{array}{c}82(42.7) \\
52(27.1) \\
38(19.8) \\
12(6.3) \\
8(4.2)\end{array}$ & $\begin{array}{l}1.30 \\
1.46 \\
1.29 \\
1.30 \\
1.69\end{array}$ & $\begin{array}{l}0.458 \\
0.499 \\
0.457 \\
0.458 \\
0.465\end{array}$ & $\begin{array}{c}\text { Chi-square } \\
\text { value } \\
-33.118\end{array}$ \\
\hline
\end{tabular}

Hypothesis H01: Age of the foreman will not have any influence on type of chits

Chi-square value at 0.05 level of significance and degree of freedom 2 is 5.488. Since the calculated value of chi square (4.95) as evident from the table 6.1 is less than the table value of chi square (5.488), the Hypothesis $\mathrm{H} 0$, age of the subscriber will not have any influence on preferring chits, is accepted. The difference between age group and the type of chits is not significant. It is also observed from the standard deviation values in the table which are ranging from 0.308 to 0.793 , as the age group of the respondents increasing, they show higher stability in type of chit funds. While the young age group i.e. below 30 years foreman have less stability in type of chit funds.

Hypothesis H02: Gender and the type of chit funds are independent

Chi-square value at 0.05 level of significance and degree of freedom 2 is 9.520. Since the calculated value of Chi-square (44.850) as evident from the table 6.1 is less than the table value of Chi-square (9.520), the Hypothesis $\mathrm{H} 0$ and age of the subscriber will not have any influence on type of chits, is accepted. The difference between age group and the type of chits is not significant. It is also observed from the standard deviation values in the table which are ranging from 1.402 to 0.859 , as the gender of the respondents increasing, they show higher stability in type of chit funds.

Hypothesis H03: Education has no effect on the type of chit funds

Chi-Square value at 0.05 level of significance and degree of freedom 5 is 11.070. Since the calculated value of chi square (1.086) as evident from the table 6.1 is less than the table value of chi square (11.070). Hypothesis H0: Education has no effect on the type of chit funds, is accepted. The difference between the Level of Education and the type of chits is not significant. Hence it is concluded that type of chit funds is independent on education.

Hypothesis H04: Income range and preference of chit funds are independent

Chi-square value at 0.05 level of significance and degree of freedom 4 is 9.488. Since the calculated value of Chi-square (33.118) as evident from the table 6.1 is greater than the table value of Chi-square (9.488). Hypothesis H0: income range and type of chit funds are independent, is rejected. The difference between income range and the type of chit funds is significant.

\section{CONCLUSIONS}

The reason why some of the chit funds companies in Tamilnadu in recent years defaulted to the customers are collecting deposits from the public by corresponding thousands of customers, assuring them high interest rates than banks and investing crore of rupees collected from the thousands of people and interested these amount in real estate business, finance business and movie making business and up with huge loses and failed to pay the amounts due to customers. These companies are collecting deposits on personal guarantee without leaving the opportunity to the count to seat their other business. Operational costs like salaries, office rent, stamp duties, paper works, and office equipment costs etc., are very high in registered chit fund companies but unregistered chit fund companies the costs is low. The $5 \%$ commission is insufficient to meet the operational costs. Though the registered chit fund companies enjoy the first bid amount without the first bid amount without any deduction the liquidity problem arises because of $100 \%$ chit amounts deposits with the unregistered chit fund companies.

\section{ACKNOWLEDGEMENT}

I would like to express my deep and sincere gratitude to my research supervisor Dr. E. Raja Justes, Professor, Department of Management Studies (Finance), Manonmaniam Sundaranar University, Tirunelveli for giving me an opportunity to do research and for providing valuable guidance throughout this research work.

\section{REFERENCES}

[1] Malyadri, G., Sudheer Kumar, B. 2013. A study on financial performance of sugar industry in India. International Journal of 
Management and Strategy. 4(6).

[2] Vivek Singla. 2013. A comparative study of financial performance of sail and Tata steel ltd. International Journal of Reviews, Surveys and Research. 2319-4618.

[3] Putra, A.P., Lahindah, L., Rismadi, B. 2014. Financial performance analysis before and after global crisis (case study in Indonesian oil and gas sector for the period of 2006-2011). Review of Integrated Business Economics Research. 3(1), 2304-1269.

[4] Sorayaei, A., Hassanpour, N., Armaki, S.M.K., Zahra. 2014. The assessing of financial performance of accepted banks in stock exchange market by means of eletere technique. American Journal of Engineering Research. 3(7), 01-06.

[5] Idhayajothi, R., Latasri, O.T.V., Manjula, N., Meharaj Banu, A., Malini, R. 2014. A study on financial performance of Ashok Leyland limited at Chennai. IOSR Journal of Business and Management. 16(6), 83-89.

[6] Siva, S., Nivetha, R. 2014. A study on financial position at whirlpool of India ltd. International Journal of Research in Management \& Business Studies. 1(2).

[7] Gupta, S. 2014. An empirical study of financial performance of icici bank - a comparative analysis. IITM Journal of Business Studies. 1(1).

[8] Tandon, M., Anjum, B., Julee. 2014. A study on financial performance of selected Indian banks. International Journal of Research in Management, Science \& Technology. 2(3).

[9] V. Srikanth. 2014. An empirical study of financial performance evaluation throws cash flow statement of an Indian manufacturing company. International Journal of Arts and Science Research. 1(1), 49-56.

[10] Shah, S.Q., Jan, R. 2014. Analysis of financial performance of private banks in Pakistan. Social and Behavioural Sciences. 109, 1021-1025.

[11] Geetha, T.N., Ramasamy, S. 2014. A study on the financial performance efficiency of selected cement industries in India. International Journal of Emerging Engineering Research and Technology. 2(3), 106-111.

[12] Velnampy, T., Anojan, V. 2014. Financial performance of state and private sector commercial banks: a comparative study during war and post war scenarios of Sri Lanka. European Journal of Business and Innovation Research, European Centre for Research Training and Development UK. 2(1), 93-105.

[13] Jothi, K., Kalaivani, P. 2015. A study on financial performance of Honda and Toyota automobile company a comparative analysis. Journal of Progressive Research in Social Sciences. 2(1).

[14] Karri, H.K., Meghani, K., Mishra, B.M. 2015. A comparative study on financial performance of public sector banks in India: an analysis on camel model. Arabian Journal of Business and Management Review (Oman chapter). 4(8).

[15] Priya, K., Palaniyammal, G. 2015. A study on financial performance analysis towards carborundam universal ltd., hosur. International Journal in Management and Social Science. 3(3).

[16] Sathya, S., Umarani, R. 2015. A study on financial performance analysis of spinning mills of Coimbatore city. International Journal of Scientific Research and Management. 3(9), 3543-3548.

[17] Pellissery, C.S., Koshy, C.J. 2015. An evaluation of financial performance of public sector banking companies and non-banking financial companies in India. International Journal of Management and Business Strategy. 4(1).

\section{Author Biography}

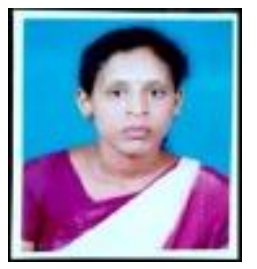

Dr. P. Shunmugathangam is now working as an Assistant Professor in the Department of Business Administration. She received Doctor of Philosophy degree in Management Studies from Manonmaniam Sundaranar University in 2017 respectively. She received Master of Commerce degree in Banking \& Insurance Management and Post Graduate Diploma degree in Finance and Taxation from Annamalai University in 2016 and in 2015 respectively. She has published various original research articles in many international journals. She received IJRULA Title Awards 2018 for Best Researcher awarded by, International Journal for Research under Literal Access and accredited with, Idamas Learning and Training Centre, Malaysia. She is working as an Editorial Board Member in the journal of International Research Journal of Engineering Technology. 